\title{
THE INFLUENCE OF EUCALYPTUS PLANTATIONS ON THE MACROFAUNA ASSOCIATED WITH Salvinia auriculata IN SOUTHEAST BRAZIL
}

\author{
CALliSTO, M., BARBOSA, F. A. R. and MORENO, P. \\ Laboratório de Limnologia/Ecologia de Bentos, Departamento de Biologia Geral, Instituto de Ciências Biológicas, \\ Universidade Federal de Minas Gerais, C.P. 486, CEP 30161-970, Belo Horizonte, MG, Brazil \\ Correspondence to: Marcos Callisto, Laboratório de Limnologia/Ecologia de Bentos, Departamento de Biologia \\ Geral, Instituto de Ciências Biológicas, Universidade Federal de Minas Gerais, C.P. 486, CEP 30161-970, \\ Belo Horizonte, MG, Brazil, e-mail: callisto@mono.icb.ufmg.br \\ Received August 28, 2000 - Accepted November 7, 2000 - Distributed February 28, 2002
}

(With 1 figure)

\begin{abstract}
The influence of Eucalyptus plantations on the structure and composition of macroinvertebrate communities associated with the aquatic fern Salvinia auriculata Aublet were investigated in a high altitude lake bordered by either secondary Atlantic forest or Eucalyptus plantations. Comparisons of the diversity of Chironomidae (Diptera, Insecta) larvae in the littoral zone between these two vegetation types showed higher diversity of larvae in waters bordered by Eucalyptus. The results demonstrated that the predominance of carnivorous taxa among the macroinvertebrate fauna appears to be the major controlling factor for limiting diversity in lake areas bordered by Eucalyptus.
\end{abstract}

Key words: Chironomidae, Chironomus, macroinvertebrates, environmental impact.

\section{RESUMO}

\section{Influência de plantações de Eucalyptus sobre a macrofauna associada a Salvinia auriculata no Sudeste do Brasil}

Foi estudada a influência de plantações de Eucalyptus sobre a composição e a estrutura de comunidades de macroinvertebrados associados à macrófita aquática Salvinia auriculata Aublet, em um lago de altitude, margeado por Mata Atlântica secundária e plantações de Eucalyptus. Comparando a diversidade de larvas de Chironomidae (Díptera, Insecta) entre as duas margens, foi evidenciada maior diversidade na margem com Eucalyptus. Os resultados obtidos mostraram que a predominância de taxa carnívoros entre a macrofauna pode ser o principal fator controlador da diversidade de organismos nas áreas circundadas por plantações de Eucalyptus.

Palavras-chave: Chironomidae, Chironomus, macroinvertebrados, impacto ambiental.

\section{INTRODUCTION}

The ecological consequences of Eucalyptus plantations on aquatic biodiversity of the littoral zone are still almost unknown to science. In Brazil, especially in the State of Minas Gerais, a significant part of the Atlantic forest was gradually replaced in the early 1920s with plantation of Eucalyptus trees. These rapidly growing trees were used for charcoal production mainly consumed by metallurgic and cellulose industries (Guerra, 1997). The Atlantic forest has been reduced to less than $7 \%$ of its original vegetation. Less than $1 \%$ is primary forest (Fonseca, 1985).

A principle impact of this gradual deforestation is surface water contamination by fertilizer (200 kg/ha on average) (Guerra, 1997) and agrochemicals, which are used to manage the 
Eucalyptus plantations. In addition, the hilly topography of Minas Gerais (in conjunction with clearcutting) increases erosion and pollution in regional lakes and streams.

Several studies have investigated the effect of Eucalyptus plantations on the structure of natural communities and their diversity (e.g., Bunn, 1988; Pozo, 1993; Canhoto \& Graça, 1995; Molinero et al., 1996; Pozo et al., 1997). Sabará (1994) also demonstrated that the monoculture of Eucalyptus produces a low-quality allochthonous contribution of carbon from the woody litter of branches, in comparison to that produced by secondary Atlantic forest whose leaves are easily decomposed.

Sabará (1994) evaluated the potential impacts of Eucalyptus plantations on two natural lakes in Minas Gerais and pointed out that the contribution of allochthonous biomass from secondary forest vegetation is ca. 2.5 times greater than that from Eucalyptus. Furthermore, the former contributes ca. 3 times more soluble carbohydrates, lipids, and crude protein.

Due to the littoral zones of freshwater ecosystems, normally have greater macroinvertebrate diversity especially in association with aquatic macrophytes than do in the lake, bottoms the richness in microhabitats, Macrophytes offer protection from predators, are a direct and indirect source of food, increase the amount of habitat per area of benthos (Newman, 1991; Humphries, 1996), and are sites for the completion of the life cycles of several aquatic and semi-aquatic organisms (e.g., Pelli, 1988, 1994). Chironomidae larvae (Diptera, Insecta) are usually present in the fauna of the littoral zone. They are excellent organisms for the study of human impacts on aquatic ecosystems because they exhibit high species richness, wide distribution, and have species that are representative of many functional groups such as shredders, gathering collectors, filter feeders, herbivores, and carnivores (Cranston, 1995; Callisto et al., 1996).

This study compared shorelines of a lake, one bordered by Eucalyptus plantations and the other by natural forest upon the composition and structure of the macrofauna associated with Salvinia auriculata. Two distinct shorelines of a natural high altitude lake were studied, one directly influenced by a Eucalyptus plantation, and the other bordered by a secondary Atlantic forest. This study examined the relationship between populations of Salvinia auriculata on two distinctly different shorelines and the diversity of its associated macrofauna during the dry and wet seasons of 1997.

\section{THE STUDY AREA}

Lagoa Teobaldo is located within the Severo Stream watershed (19³0'84"S; 4247'28"W; 900 $\mathrm{m}$ altitude), a tributary of the Piracicaba River in Minas Gerais. The lake has a triangular shape, an area of $10 \mathrm{ha}$, a maximum depth of $7.0 \mathrm{~m}$, and a mean depth of $1.3 \mathrm{~m}$. The lake is relatively warm with temperatures ranging between $18.2^{\circ} \mathrm{C}$ (dry season) to $27.0^{\circ} \mathrm{C}$ (rainy season). The lake waters tend to be acidic during the rainy period $(\mathrm{pH}=$ 5.2), and neutral $(\mathrm{pH}=7.0)$ during the dry period. The oxygen concentration shows considerable variation between $0.2 \mathrm{mg} / \mathrm{L}$ during the rainy period and $10.4 \mathrm{mg} / \mathrm{L}$ during the dry period. Electrical conductivity ranges between $8.5 \mu \mathrm{S} / \mathrm{cm}$ during the dry season to $59.5 \mu \mathrm{S} / \mathrm{cm}$ during the rainy season. Increased conductivity during the rainy season is indicative of greater allochtonous inputs during this period. Ammonium $\left(\mathrm{NH}_{4}^{+}\right)$is the dominant form of nitrogen in the water column and during this study it increased up to $221.8 \mu \mathrm{g} / \mathrm{L}$ during the rainy season. The highest recorded nitrate $\left(\mathrm{NO}_{3}^{-}\right)$level was $81.8 \mu \mathrm{g} / \mathrm{L}$ during the dry season. Nitrate nitrogen normally stays below $11 \mu \mathrm{g} / \mathrm{L}$ for most of the year. Soluble phosphorus ranged between 2.0 and $30.3 \mu \mathrm{g} / \mathrm{L}$ during the wet and dry seasons, respectively.

\section{MATERIAL AND METHODS}

In situ measurements of temperature, $\mathrm{pH}$, dissolved oxygen, and electrical conductivity, were made using a H 20 Water Quality Multiprobe (Hydrolab). Water samples were collected with a Van Dorn bottle and fixed for subsequent chemical analysis using the techniques of Mackereth et al. (1978) and Golterman et al. (1978). Samples of S. auriculata were collected in triplicate using a hand net $\left(250 \mu \mathrm{m}\right.$ mesh, $\left.0.625 \mathrm{~m}^{2}\right)$ during the dry and rainy periods of 1997. Samples were preserved with formaldehyde solution (10\%) for later analysis. The $S$. auriculata samples were rinsed through a $250 \mu \mathrm{m}$ mesh sieve and insects sorted under a stereomicroscope. Identification of ma- 
croinvertebrates was performed according to Wiederholm (1983), Merritt \& Cummins (1988), Epler (1995), and Pescador (1997). Chironomidae larvae were identified at $400 \mathrm{X}$ after mounting using a $10 \%$ lactophenol solution. Richness, density, and Shannon diversity at base 2 were calculated after larvae identification.

\section{RESULTS AND DISCUSSION}

At both shorelines, the results showed that the stand of $S$. auriculata is the preferred site (ca. $80 \%$ total organisms) for macroinvertebrate colonization when compared to the leaves. The majority of organisms were fixed to plant detritus attached to the roots, probably attracted by bacteria, fungi, and yeasts living on the plant detritus. For the $S$. auriculata populations bordered by Eucalyptus plantations, undecomposed bark and leaves predominated which probably limited colonization by macroinvertebrates. The shoreline bordered by secondary forest was observed to have highly decomposed material, and a higher observed total number of macroinvertebrates.

Numerically, macroinvertebrates were mainly represented by Chironomidae larvae $(55.63 \% \pm$ $4.87 \%)$, Oligochaeta $(17.1 \% \pm 10.5 \%)$, the Odonata $(4.1 \% \pm 3.2 \%)$, and the Amphipoda Gammaridae $(7.6 \% \pm 6.5 \%)$ (Table 1). Planariidae, Hydracarina, Ephemeroptera, Lepidoptera, Coleoptera, Heteroptera, Diptera, Ceratopogonidae, Culicidae, Stratiomyidae, and Tipulidae were found in low numbers. Among the Chironomidae larvae, 18 genera were identified, not including those belonging to the tribe Tanytarsini, most of which have not yet been described for this neotropical region (Fittkau \& Reiss, 1973).

Since Chironomidae dominates the macrofauna and thus have an important ecological role in this lake community, we grouped them into five major categories: a) carnivores, mainly represented by Ablabesmyia, Labrundinia, and Tanypus; b) miners, represented by Goeldichironomus, Beardius, Polypedilum, Nimbocera, Parachironomus, Asheum, Harnischia, Phaenopsectra, and Xestochironomus (following Epler, 1995); c) indicators of eutrophic conditions, i.e., well adapted to low oxygen concentrations such as Cladopelma, Chironomus, and Phaenopsectra (Wiederholm, 1983); d) taxa characteristic of high altitudes, mainly represented by Nanocladius (Cranston, 1995); and e) other common genera such as Rheotanytarsus, and Tanytarsini genera varia. Genera of the Orthocladiinae (e.g., Nanocladius and Orthocladius) might be expected to be found in Lagoa Teobaldo because of its high altitude. Genera belonging to the subfamilies Tanypodinae and Chironominae were also found within the sediments (unpublished data) underneath the dense populations of Salvinia auriculata.

It was observed that the increase of allochthonous organic matter into the littoral zone during the rainy period enhanced resources available to the macroinvertebrate community by presenting new opportunities for colonization, refuge, and foraging. Increased inputs of allochthonous carbon directly results in an increase in Chironomidae larvae diversity. However, increased pressure from predators also occurred during the rainy season because of the increase in nymphae of Odonata and larvae of Ablabesmyia and Labrundinia (Table 1). These observations are supported by increases registered in richness, equitability, and Shannon diversity index ( $<<0.05)$ (Fig. 1).

During the rainy period, the taxonomic composition of Chironomidae larvae associated with populations of Salvinia auriculata on the shorelines influenced by Eucalyptus plantations showed a decreased number of carnivorous taxa and an increase in general diversity $(\mathrm{p}<0.05)$. In contrast, during the dry period, the number of carnivorous taxa increased and biodiversity decreased ( $\mathrm{p}<$ $0.05)$. A similar trend was noted for the macrophyte community, associated with $S$. auriculata, bordered by natural vegetation (Fig. 1).

Our results show a distinct relationship between shoreline vegetation, the composition of the macrofauna community, and the health and density of $S$. auriculata populations on the two shorelines. A more stable community structure was observed in the littoral zone bordered by natural vegetation (no significant changes in species composition and total area used between dry and rainy periods). For the littoral zone bordered by Eucalyptus plantations, populations of less developed S. auriculata occurred (lower number of leaves and less developed stand), with an associated community formed by organisms with smaller body size, lower diversity, and dominated basically by Chironomidae larvae and a few Odonata. 


\section{TABLE 1}

Density (ind $\left./ \mathrm{m}^{2}\right)$ and standard deviation, relative percentage $\left(\%\right.$ ind $\left./ \mathrm{m}^{2}\right)$ of macroinvertebrates associated with Salvinia auriculata (Aublet) stands at Lagoa do Teobaldo, Southeast Brazil, surrounded by natural vegetation and Eucalyptus spp. plantation during rainy and dry periods of 1997.

\begin{tabular}{|c|c|c|c|c|}
\hline \multirow{2}{*}{ Taxa } & \multicolumn{2}{|c|}{ Natural vegetation } & \multicolumn{2}{|c|}{ Eucalyptus plantation } \\
\hline & Rainy & Dry & Rainy & Dry \\
\hline Planariidae & - & - & - & $7 \pm 3(0.2)$ \\
\hline Oligochaeta & $1,918 \pm 25(0.1)$ & $273 \pm 3(10.6)$ & $798 \pm 15(16.0)$ & $315 \pm 30(9.6)$ \\
\hline Hydracarina & $7 \pm 2(0.1)$ & $7 \pm 1(0.3)$ & $14 \pm 6(0.3)$ & - \\
\hline Aracnida (terrestrial) & $7 \pm 1(0.1)$ & & $7 \pm 5(0.1)$ & - \\
\hline Amphipoda Gammaridae & $273 \pm 13(4.7)$ & $420 \pm 5(16.3)$ & $49 \pm 2(1.0)$ & $280 \pm 18(8.4)$ \\
\hline Ephemeroptera & $42 \pm 12(0.7)$ & $56 \pm 3(2.2)$ & $364 \pm 19(7.2)$ & $7 \pm 3(0.2)$ \\
\hline Lepidóptera & $7 \pm 3(0.1)$ & - & - & - \\
\hline Coleóptera & $35 \pm 5(0.6)$ & $21 \pm 4(0.8)$ & $28 \pm 9(0.6)$ & $28 \pm 4(0.8)$ \\
\hline Odonata & $329 \pm 12(5.5)$ & $42 \pm 7(1.6)$ & $406 \pm 29(8.0)$ & $42 \pm 5(1.3)$ \\
\hline $\begin{array}{l}\text { Trichoptera } \\
\text { Polycentropodidae }\end{array}$ & - & - & - & $21 \pm 6(0.6)$ \\
\hline Polycentropus (larvae) & $7 \pm 4(0.1)$ & $49 \pm 8(2.0)$ & - & $14 \pm 2(0.4)$ \\
\hline \multicolumn{5}{|l|}{$\begin{array}{l}\text { Heteroptera } \\
\text { Belastomatidae }\end{array}$} \\
\hline Belostoma (nymphs) & - & $14 \pm 2(0.5)$ & $63 \pm 3(1.3)$ & $7 \pm 3(0.2)$ \\
\hline Belostoma (adult) & - & $7 \pm 3(0.3)$ & - & - \\
\hline Naucoridae & $42 \pm 2(0.7)$ & $14 \pm 2(0.5)$ & $21 \pm 5(0.4)$ & $7 \pm 3(0.2)$ \\
\hline Notonectidae & $21 \pm 3(0.3)$ & - & $42 \pm 3(0.8)$ & $21 \pm 2(0.6)$ \\
\hline Gerridae & $7 \pm 1(0.1)$ & $7 \pm 2(0.3)$ & $14 \pm 5(0.3)$ & - \\
\hline Díptera & $7 \pm 1(0.1)$ & - & - & $7 \pm 2(0.2)$ \\
\hline Ceratopogonidae & $56 \pm 3(0.9)$ & $224 \pm 12(8.7)$ & - & $791 \pm 55(23.9)$ \\
\hline Culicidae & $21 \pm 1(0.3)$ & - & - & - \\
\hline Stratiomyidae & $14 \pm 4(0.2)$ & $7 \pm 3(0.3)$ & - & $28 \pm 4(0.8)$ \\
\hline Pupae of Chironomidae & $77 \pm 5(1.3)$ & $35 \pm 5(1.4)$ & $112 \pm 3(2.2)$ & $77 \pm 6(2.3)$ \\
\hline Tipulidae & - & - & - & $7 \pm 1(0.2)$ \\
\hline \multicolumn{5}{|l|}{ Chironomidae (larvae) } \\
\hline \multicolumn{5}{|l|}{ Orthocladiinae } \\
\hline Nanocladius & - & $14 \pm 3(0.5)$ & - & - \\
\hline Orthocladius & - & - & $7 \pm 1(0.1)$ & - \\
\hline \multicolumn{5}{|l|}{ Tanypodinae } \\
\hline Ablabesmyia & $1,645 \pm 215(27.7)$ & $1,043 \pm 67(40.6)$ & $644 \pm 54(12.8)$ & $1,120 \pm 328$ \\
\hline Labrundinia & $1,057 \pm 257(17.8)$ & $203 \pm 119(7.9)$ & $392 \pm 112(7.8)$ & $343 \pm 65(10.4)$ \\
\hline Procladius & - & $21 \pm 2(0.8)$ & - & - \\
\hline Tanypus & - & - & $14 \pm 8(0.3)$ & $98 \pm 17(2.9)$ \\
\hline \multicolumn{5}{|l|}{ Chironominae } \\
\hline Asheum & - & - & $7 \pm 4(0.3)$ & - \\
\hline Beardius & - & $21 \pm 7(0.8)$ & $175 \pm 35(3.5)$ & $28 \pm 11(0.8)$ \\
\hline Cladopelma & - & - & $609 \pm 112(12.0)$ & - \\
\hline Chironomus & $21 \pm 3(0.3)$ & - & $735 \pm 25(14.6)$ & - \\
\hline
\end{tabular}


TABLE 1 (Continued)

\begin{tabular}{|l|c|c|c|c|}
\hline \multirow{2}{*}{ Taxa } & \multicolumn{2}{c|}{ Natural vegetation } & \multicolumn{2}{c|}{ Eucalyptus plantation } \\
\cline { 2 - 5 } & Rainy & Dry & Rainy & Dry \\
\hline Goeldichironomus & $154 \pm 31(2.6)$ & $35 \pm 12(1.4)$ & $77 \pm 17(1.5)$ & $28 \pm 13(0.8)$ \\
\hline Harnischia & $28 \pm 11(0.5)$ & $7 \pm 3(0.3)$ & - & - \\
\hline Parachironomus & - & - & $14 \pm 8(0.3)$ & $21 \pm 3(0.6)$ \\
\hline Phaenopsectra & $7 \pm 3(0.1)$ & - & $42 \pm 12(0.8)$ & - \\
\hline Polypedilum & $28 \pm 11(0.5)$ & $42 \pm 4(1.6)$ & $98 \pm 31(1.9)$ & $21 \pm 11(0.6)$ \\
\hline Xestochironomus & $7 \pm 2(0.1)$ & - & - & - \\
\hline Nimbocera & $7 \pm 2(0.1)$ & - & $154 \pm 25(3.0)$ & $7 \pm 3(0.2)$ \\
\hline Rheotanytarsus & $21 \pm 5(0.3)$ & - & $14 \pm 1(0.3)$ & - \\
\hline Tanytarsini genera varia & $112 \pm 11(1.9)$ & - & $147 \pm 13(2.9)$ & - \\
\hline Total & $5,957(100)$ & $2,569(100)$ & $5,040(100)$ & $3,325(100)$ \\
\hline
\end{tabular}

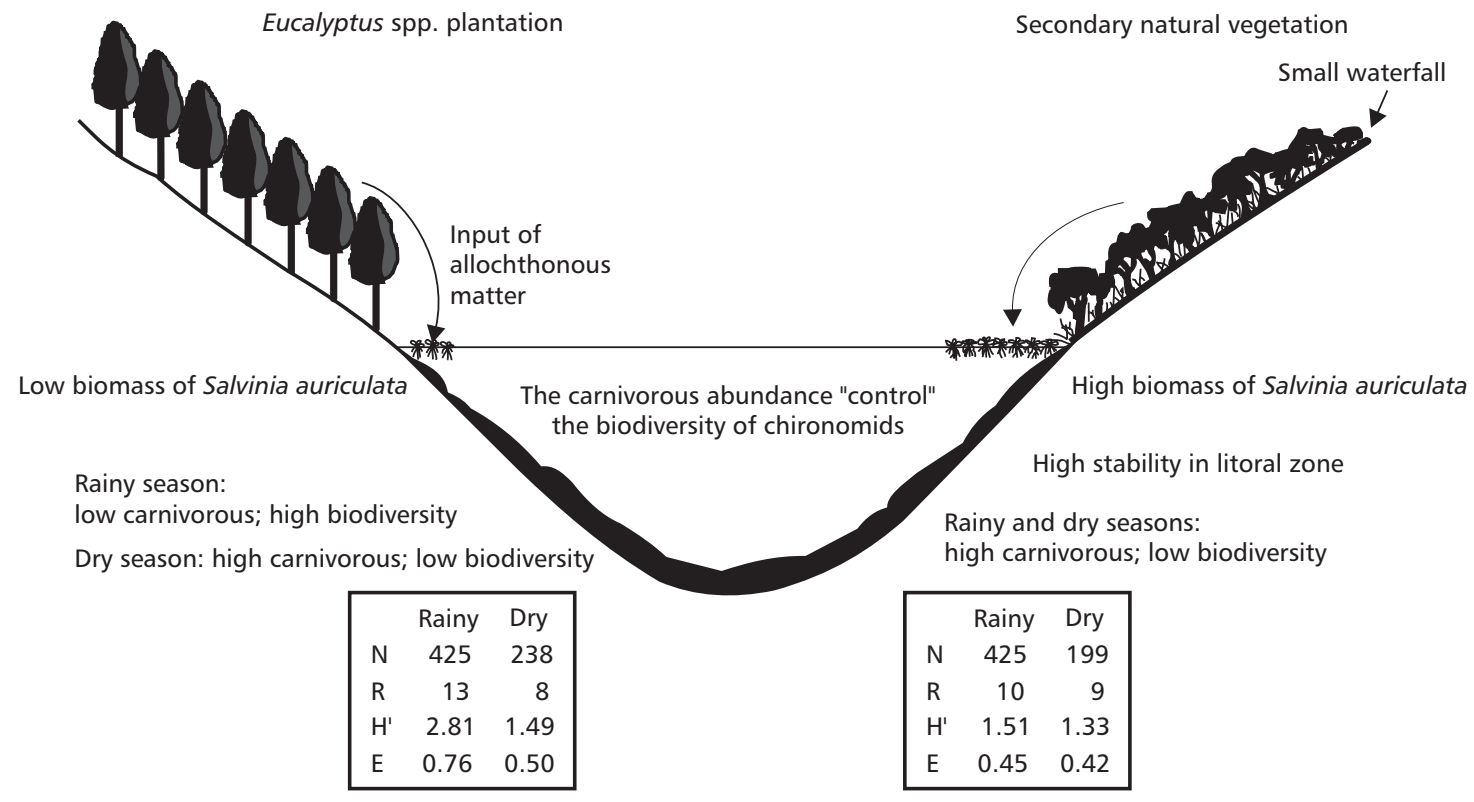

Fig. 1 - Diagram of the main ecological characteristics of Lagoa do Teobaldo in the rainy and dry seasons of 1997. Note the differences comparing the littoral zone near vegetation of Eucalyptus spp. plantation to the littoral zone near secondary natural vegetation. $\mathrm{N}=$ number of individuals, $\mathrm{R}=$ taxonomic richness of chironomids, $\mathrm{H}^{\prime}=$ Shannon diversity at base $2, \mathrm{E}=$ evenness.

Where the littoral zone is bordered by natural vegetation, the floating populations of $S$. auriculata are dense and have plants with more leaves and more developed stands. In this area, no differences were observed in the diversity of macroinvertebrates between the dry and rainy periods.

Similar conclusions were reached by Humphries (1996) who found greater total abundance of individuals, taxonomic richness, and abundance of most of the commonest taxa of phytophilous macroinvertebrates in the macrophyte communities with the most complex structure. This author also stated that differences in total invertebrate abundance among macrophyte species cannot be explained only by differences in plant biomass or water depth. Other vegetational variables such as plant surface area, 
number of available microhabitats, and/or other factors may play a key role in macrofaunal colonization.

In summary, our results clearly suggest that dense, healthy populations of $S$. auriculata can support higher diversity and more stable populations of macroinvertebrates. On the other hand, our results demonstrated a higher diversity of Chironomidae larvae associated with Salvinia auriculata at the littoral zone surrounded by Eucalyptus plantations when compared with the area surrounded by natural vegetation. This, suggests no impact of this planted vegetation on diversity of the Chironomid assemblage. However, changes in the community structure and taxonomic composition were evident, probably due to the differences in microhabitats and the pressure exerted by the carnivorous taxa (specially Tanypodinae).

Acknowledgments - We are indebted for logistic facilities in the field to the Municipal Government of Antônio Dias (Minas Gerais), and to colleagues of the Laboratory of Limnology for their assistance. We are grateful to MSc. Angela Sanseverino (Zoological Museum of Muniche) for her criticism. Professor David Biesboer (University of Minnesota, Department of Plant Biology) made valuable comments and suggestions on the manuscript. Dr Alexandre Salino identified macrophyte species. This work was supported by Fundação de Amparo à Pesquisa do Estado de Minas Gerais (Fapemig) and Conselho Nacional de Desenvolvimento Científico e Tecnológico (CNPq).

\section{REFERENCES}

BUNN, S. E., 1988, Processing of leaf litter in two northern jarrah forest streams, western Australia: II. The role of macroinvertebrates and the influence of soluble polyphenols and inorganic sediment. Hydrobiologia, 162: 211-223

CALLISTO, M., SERPA-FILHO, A., DE OLIVEIRA, S. J. \& ESTEVES, F. A., 1996, Chironomids on leaves of Typha domingensis in a lagoon of Rio de Janeiro State (Brazil). Stud. on the Neotrop. Fauna and Environ., 31: 51-53.

CANHOTO, C. \& GRAÇA, M. A. S., 1995, Food value of introduced eucalyptus leaves for a Mediterranean Stream detritivore: Tipula lateralis. Freshwater Biology, 34: 209-214.

CRANSTON, P. S., 1995, Biogeography. In: P. Armitage, P. S. Craston \& L. C. V. Pinder (eds.), The Chironomidae: The biology and ecology of non-biting midges. Chapman Hall, pp. 62-84.

EPLER, J. H., 1995, Identification manual for the larval Chironomidae (Diptera) of Florida. $2^{\text {nd }}$ ed. Departament of Environmental Regulation, State of Florida.

FITTKAU, E. J. \& REISS, F., 1973, Amazonische Tanytarsini (Chironomidae, Diptera) I. Die riopreto-Gruppe der Gattung Tanytarsus. Stud. Neotrop. Fauna and Environ., 8: 1-16.
FONSECA, G. A. B., 1985, The vanishing Brazilian Atlantic Forest. Biological Conservation, 34(1): 17-340.

GOLTERMAN, H. L., CLYMO, R. S. \& OHNSTAD, M. A M., 1978, Methods for physical and chemical analysis of freshwater. Blackwell Scientific Publication, Londres, $214 \mathrm{p}$.

GUERRA, C. B., 1997, Environment and work in the Eucalyptus world: a case study from the Piracicaba River region, in Minas Gerais, Brazil. Conferência IUFRO sobre Silvicultura e Melhoramento de Eucaliptos, Salvador, pp. 17-24.

HUMPHRIES, P., 1996, Aquatic macrophytes, macroinvertebrate associations and water levels in a lowland Tasmanian River. Hydrobiologia, 321(3): 219-233.

MACKERETH, F. J. H., HERON, J. \& TALLING, J. F. 1978, Water analysis: some revised methods for limnologists. Freshwater Biological Association, Cumbria, n. 36, 120p.

MERRITT, R. W. \& CUMMINS, K. W., 1988, An introduction to the aquatic insects of North America. $2^{\text {nd }}$ ed. Kendall/Hunt, 758p.

MOLINERO, J., POZO, J. \& GONZÁLES, E., 1996, Litter breakdown in streams of the Agüera catchment: influence of dissolved nutrients and land use. Freshwater Biology, 36: 745-756.

NEWMAN, R. M., 1991, Herbivory and detritivory on freshwater macrophytes by invertebrates: a review. J. North Am. Benthol. Soc., 10: 89-114.

PELLI, A., 1988, Ecologia de insetos aquáticos associados ao órgão submerso de Salvinia herzogii na Lagoa Olhos d'Água, Lagoa Santa, MG. Monographya, Universidade Federal de Minas Gerais, 67p

PELLI, A., 1994, Taxas de crescimento de Salvinia molesta Mitchell e sua entomofauna associada em um lago do Planalto de Lagoa Santa, MG. Dissertação de Mestrado, Universidade Federal de Minas Gerais, PPGECMS, Belo Horizonte, MG.

PESCADOR, M. L., 1997, General ecology of mayflies: adaptations, reproductive strategies and trophic categories. In: Bioindicadores ambientales de calidad de agua. Universidad del Valle, Colombia.

POZO, J., 1993, Leaf litter processing of alder and eucalyptus in the Agüera Stream system (North Spain) I. Chemical changes. Archiv für Hydrobiol., 127: 299-317.

POZO, J., GONZÁLEZ, E., DÍEZ, J. R., MOLINERO, J. \& ELÓSEGUI, A., 1997, Inputs of particulate organic matter to streams with different riparian vegetation. J. North Am. Benthol. Soc., 16(3): 602-611.

SABARÁ, M. G., 1994, Avaliação dos impactos do plantio de Eucalyptus spp., sobre dois lagos naturais no médio Rio Doce, MG: propostas de mitigação e manejo. Dissertação de Mestrado, UFMG, PPGECMVS, MG, $156 \mathrm{p}$.

WIEDERHOLM, T. (ed.), 1983, Chironomidae of the Holarctic region. Keys and diagnoses. Part 1. Larvae. Entomol. Scandinavica Suppl., 19: 1-457. 